able for the product of the two (probably unequal) propagation frequency factors and should be compared with the value of $10^{12}$ litre $^{2}$ mole $^{-2}$ sec.-2 for the product of two successive (equal) propagation frequency factors in styrene.

We wish to express our thanks to the Royal Society and the Chemical Society for grants made in aid of this investigation.

Note added in proof, October 4, 1948.-We have now obtained direct experimental verification of points (1) and (2) in section $(a)$. Thus, in 1-butene polysulphone formation $T_{6}$ depends on $[\mathrm{Bu}]\left[\mathrm{SO}_{2}\right]$ exactly as predicted in equation (8); the heat of reaction for 1-butene is $22 \cdot 0 \pm 0.7$ and for 2 -butene is $20.5 \pm 1.7 \mathrm{k} . c a l$., indicating that the lower $T_{c}$ for the latter is due to the smaller $q$, as suggested. (We are indebted to Mr. D. G. L. James for help with the adiabatic calorimetry.)

${ }^{2}$ Taylor and Tobolsky, J. Amer. Chem. Soc., 67, 2063 (1945).

${ }^{2}$ Tobolsky and Mesrobian, $J$.Amer. Chem. Soc., 6\%, 785 (1945); $J$. Polymer Sci., 2, 463 (1946); Tobolsky and Blatz, J. Phys. Coll. Chem., 49, 77 (1945).

${ }^{3}$ Grassie and Melville, Trans. Faraday Soc., contribution to discussion on "Labile Molecule" held in September 1947.

${ }^{4}$ Details will be published elsewhere.

${ }^{5}$ The ceiling temperature phenomenon in the copolymerization of sulphur dioxide and olefines was discovered in 1938 by Snow and Frey ${ }^{7}$. The cause was then unknown.

- Bamford and Dewar, Proc. Roy. Soc., A, 192, 309 (1948).

' Snow and Frey, Ind. Eng. Chem., 30, 176 (1938); J. Amer. Chem. Soc., 65, 2417 (1943).

8 Glasstone, Laidler and Eyring, "Theory of Rate Processes" (McGrawHill, 1941).

- Tong and Kenyon, $J$. Amer. Chem. Soc., 69, 1402 (1947).

\section{UNIVERSITY OF BERGEN}

$\mathrm{T}$ HE University of Bergen was opened on August 30 by the Crown Prince of Norway. At the same time three hundred new students were matriculated and welcomed.

The University of Bergen starts with three faculties, namely, mathematics and natural sciences, humanities, and medicine. It will be further built up in accordance with plans prepared by a committee for the University, which forwarded its proposals to the executive body so long ago as 1939 .

The Faculty of Mathematics and Natural Sciences and the Faculty of the Fumanities are being developed from the old and well-known institution, the Bergen Museum, whereas the Faculty of Medicine is based on the municipal hospitals and the State gynæcological hospital in Bergen. From August 30, 1948, these different institutes are associated together in a common scientific institution, the University of Bergen.

The Bergen Museum already had ten different departments, eight of which now belong to the Faculty of Mathematics and Natural Sciences. These departments are the following: (1) Zoology, professorship for the moment vacant. (2) Mineralogy and geology, Prof. N.-H. Kolderup. (3) Systematic botany, with a botanic garden, Prof. K. Fægri. The collections belonging to these departments are kept in the old main building of the former Bergen Museum. A biological station built in 1927 at Herdla in the neighbourhood of Bergen is associated with the Department of Zoology. (4) General botany, Prof. O. Hagem. (5) Chemistry (and biochemistry), Prof. T. Gaarder. In the Geophysical Institute, which was built in 1928 in the neighbourhood of the main building of the Bergen Museum, three different departments have laboratories, offices and workshops: (6) Oceanography, Prof. H. Mosby. (7) Meteorology, Prof. C.-L. Godske. (8) Cosmic physics with terrestrial magnetism, Prof. B. Trumpy. According to the plans of the committee of 1939, the Department of Cosmic Physics will take over the duties of a Department of Physics at the new University. Two new institutes are now being built in the neighbourhood of the Geophysical Institute. According to present plans, these buildings will be completed and come into use during the session 1949-50. They will provide laboratories, offices and workshops for the Departments of Chemistry, General Botany and Physies.

It may be mentioned that on the initiative of o. Dahl and B. Trumpy a laboratory building for nuclear physies has just been completed to plans drawn up by them. In the near future it is hoped to begin work on the installation of a $1 \cdot 8-\mathrm{MeV}$. van de Graaff generator and a $50-\mathrm{MeV}$. betatron in this building. The Institute of Nuclear Physics, which has been built by the aid of funds not appearing in the University budget, will nevertheless in the future be the property of the University.

Funds for a professorship in mathematies have been granted from the beginning of the year 1948-49; and an appointment will be made in the near future.

At the present time, the Faculty of the Fumanities consists of two departments only. The corresponding departments of the former Bergen Museum, namely, the Department of Archæology (Prof. Johs. Böə), with valuable collections relating to the old history of Norway in the new Museum (1927), and the Department of Norwegian Philology (Prof. O. Skulerud), have been taken over unchanged by the University.

A professorship in philosophy is vacant; a new professor will be appointed in the near future. For the moment, a number of temporarily appointed instructors are lecturing on different subjects belonging to the Faculty of the Humanities, as, for example, philosophy, Latin, general philology, phonetics, and different living languages such as Norwegian, English, French and German. It is to be hoped that the Norwegian Government will encourage the rapid development of the new University by establishing the necessary new teaching posts in the Faculty of Mathematics and Natural Sciences, as well as in the Faculty of the Humanities.

As mentioned before, the Faculty of Medicine is based upon the municipal hospital in BergenHaukeland Sykehus-and the State gynæcological hospital in Bergen. The instruction of medical students started at these hospitals in 1946 as a subsection of the Faculty of Medicine of the University of Oslo. From August 30, 1948, the section in Bergen has been working as an independent faculty at the new University.

Medical studies in Bergen will for the present be purely clinical. Instruction in the pre-clinical subjects will temporarily be given only at the University of Oslo. Indeed, the institutes of anatomy and physiology in Oslo have a considerably greater capacity for instruction than the clinical departments ; consequently the extension of the possibilities of clinical studies by the foundation of a Faculty of Medicine at Bergen had become very desirable.

The departments of the Faculty of Medicine at the University of Bergen are as follow : gynæcology and obstetries (Prof. J. Lövset); pathology (Prof. E. Waaler); surgery (Prof. H. Gade); clinical medicine (Prof. H. Rasmussen); dermato-venerology 
(Prof. I. Rokstad) ; psychiatry (Prof. F. Rud); bacteriology (Prof. Th. M. Vogelsang); roentgenology (Prof. S. N. Bakke). Instruction is also given in pharmacology, orthopædics and hygiene.

On July 9, 1948, an act creating the University of Bergen was sanctioned by the King's order in council. It was decided that the University, during a transition period, should be governed by a temporary senate, consisting of: Prof. B. Trumpy, Rector of the University; Prof. E. Waaler, dean of the Faculty of Medicine; Prof. N.-H. Kolderup, dean of the Faculty of Mathematics and Natural Sciences; and Prof. Johs. Böe, dean of the Faculty of the Fiumanities.

\section{B. TRUMPY}

\section{RULES OF ZOOLOGICAL NOMENCLATURE}

$\mathrm{D}^{2}$ URING the thirteenth International Congress of Zoology, which closed in Paris on July 27, the International Commission on Zoological Nomenclature, holding its first meeting since the close of the Second World War, put forward a comprehensive programme for the reform and development of zoological nomenclature. All the thirteen meeting; held by the Commission were open to all the members of the Congress, who were thus enabled to take an active part in the discussion of the proposals put forward by the Commission. As a result it was possible not only to obtain decisions on a much larger number of questions than would otherwise have been practicable, but also to ascertain much more readily the needs and general wishes of zoologists. The scheme finally adopted was approved unanimously by the Section on Nomenclature and, on the recommendation of the Section, by the Congress itself at its final plenary session.

Prior to the opening of the Paris meeting, extensive discussions had been undertaken by the Commission with leading scientific institutions and individual specialists in different parts of the world, with the double purpose of drawing up a scheme which would ensure for the Commission the highest possible representative and international character, and would secure that at the Paris meeting all practicable measures should be taken to improve and develop the Règles Internationales de la Nomenclature Zoologique.

Measures taken to secure a fully representative and international character for the Commission. Hitherto the International Commission has had a fixed membership of eighteen commissioners, but in future there will be no fixed upper limit to its membership, though the number of eighteen will be retained as the minimum membership. Under the new system it will be possible therefore for the zoologists of any country in which any considerable body of zoological work is being carried out to have direct representation on the Commission. The change now made will make it possible also for the Commission to call to its membership leading specialists in particular fields irrespective of country. Machinery is at the same time provided for consultation with the leading scientific institutions in any country in regard to the selection of its representative on the Commission.

Measures taken to reform the procedure of the Commission. The extensive series of changes in the procedure of the Commission are designed to secure that in future the Commission shall be able to reach decisions much more rapidly than has been possible in the past. The most important single reform is the abandonment of the Liberum Veto under which either during a meeting or when business is conducted by correspondence a single member of the Commission could prevent any decision being taken by the Commission either in the formulation of recom. mendations for the improvement of the Règles, or in the use of the plenary powers given to the Commission to conserve zoological names which are in common use but are technically defective. Other reforms agreed upon are designed to eliminate all unnecessary delay in the consideration of nomenclatorial problems submitted to the Commission by specialists. It is hoped that under this revised procedure it will normally be possible for the Commission to promulgate its decision on any question put to it within eighteen months of the date of the application.

Reform and development of the Regles. At the opening of the Paris meeting, the Regles in force were substantially the same as those which had been adopted at the Congress of Zoology held in Berlin in 1901. The object of the reforms now agreed upon is to clarify the text of the Règles, which experience has shown to be in many cases obscure, to make the Règles more comprehensive by introducing provisions on questions not hitherto included in that instrument and, where necessary, to introduce changes into them in order to bring their provisions into harmony with general wishes. By these means it is hoped to retain everything that experience has shown to be valuable, to eliminate all those passages which have been found to be unsatisfactory, and to meet the needs of zoologists by the introduction of provisions on matters which have hitherto not been subject to international regulation.

Codification of the international law on zoological nomenclature. A large part of existing international law on zoological nomenclature is to be found not in the Règles themselves but in "Opinions" rendered by the International Commission acting in the judicial capacity entrusted to it by the International Zoological Congress at Boston in 1907. The complex body of case law which has thus grown up over the last forty years has made the task of zoologists extremely difficult. A wide welcome will therefore be given to the decision now taken in Paris to codify the law by incorporating in the Regles themselves the decisions hitherto embodied only in the "Opinions" of the Commission. Another reform of great practical value is afforded by the decision to record in special schedules attached to the Regles the decisions taken by the Commission in particular cases. With regard to decisions to be taken by the Commission in the future, these will be of either of two kinds: (1) decisions on matters of principle which will be issued as Declarations and take the form of proposed amendments to be incorporated in the Regles after approval by the next Congress; and (2) decisions on individual cases which will be issued as Opinions and which after the next Congress will be inserted in the appropriate schedule to the Regles. Thus the Commission intends to ensure that in future a zoologist will be able to find the whole body of international law in regard to zoological nomenclature within the covers of a single volume.

Preparation and promulgation of the revised substantive French text of the Regles. Recognizing the highly technical problems inevitably involved in the preparation of a substantive text giving effect to the numerous changes which have now been agreed upon, 